\title{
Rearrangements and Deletions of Immunoglobulin Heavy Chain Genes in the Double-Producing B Cell Lymphoma I.29
}

\author{
JANET STAVNEZER, ${ }^{1 *}$ KENNETH B. MARCU,${ }^{2}$ SONIA SIRLIN,${ }^{1}$ BECKY ALHADEFF, ${ }^{1}$ AND \\ ULRICH HAMMERLING ${ }^{1}$ \\ Molecular Biology and Genetics Unit of the Graduate School for Medical Sciences, Sloan-Kettering Division, \\ New York, New York 10021, ${ }^{1}$ and Biochemistry Department, State University of New York, Stony Brook, \\ New York $11794^{2}$
}

Received 16 November 1981/Accepted 28 April 1982

\begin{abstract}
The B cell lymphoma I.29 consists of a mixture of cells expressing membranebound immunoglobulin $M(\operatorname{IgM})(\lambda)$ and $\operatorname{IgA}(\lambda)$ of identical idiotypes. Whereas most of the cells express either IgM or IgA alone, 1 to $5 \%$ of the cells in this tumor express IgM and IgA simultaneously within the cytoplasm and on the cell membrane (R. Sitia et al., J. Immunol. 127:1388-1394, 1981; R. Sitia, unpublished data). When $\mathrm{IgM}^{+}$cells are purified from the lymphoma and passaged in mice or cultured, a portion of the cells convert to $\operatorname{IgA}^{+}$. These properties suggest that some cells of the I.29 lymphoma may undergo immunoglobulin heavy chain switching, although it is also possible that the mixed population was derived by a prior switching event in a clone of cells. We performed Southern blotting experiments on genomic DNAs isolated from populations of I.29 cells containing variable proportions of $\mathrm{IgM}^{+}$and $\mathrm{IgA}^{+}$cells and on a number of cell lines derived from the lymphoma. The results were consistent with the deletion model for heavy chain switching, as the $\operatorname{IgM}^{+}$cells contained rearranged $\mu$ genes and $\alpha$ genes in the germ line configuration on both the expressed and nonexpressed heavy chain chromosomes, whereas the $\operatorname{Ig} \mathrm{A}^{+}$cells had deleted both $\mu$ genes and contained one rearranged and one germ line $\alpha$ gene. In addition, segments of DNA located within the intervening sequence $5^{\prime}$ to the $\mu$ gene, near the site of switch recombination, were deleted from both the expressed and the nonexpressed chromosomes. Although $\mu$ genes were deleted from both chromosomes in the $\mathrm{IgA}^{+}$cells, the sites of DNA recombination differed on the two chromosomes. On the expressed chromosome, $S \mu$ sequences were recombined with $S \alpha$ sequences, whereas on the nonexpressed chromosome, $S \mu$ sequences were recombined with $S \gamma 3$ sequences.
\end{abstract}

During differentiation, a clone of B lymphocytes shifts from the synthesis of immunoglobulin M (IgM) to the synthesis of other classes of immunoglobulins while continuing to express the same variable $\left(V_{H}\right)$ domain $(1,10,19,29$, 30). As the class of immunoglobulin is determined by the constant region of the immunoglobulin heavy $(\mathrm{H})$ chain $\left(\mathrm{C}_{\mathrm{H}}\right)$ region, the $\mathrm{B}$ cell must switch from the expression of the $C \mu$ gene to the expression of other $\mathrm{C}_{\mathrm{H}}$ genes. By examining the DNA of myeloma and hybridoma cells, it has been concluded that $\mathrm{H}$ chain switching is effected by deletion of the $C_{H}$ genes (and their flanking sequences) located between the expressed $V_{\mathrm{H}}-D-J_{\mathrm{H}}$ gene and the newly expressed $\mathrm{C}_{\mathrm{H}}$ gene $(5,8,12,12 \mathrm{a}, 14,45)$.

Plasmacytoma and hybridoma cells are terminally differentiated cells which are generally not capable of $\mathrm{H}$ chain switching. Hence, compari- sons of the $\mathrm{H}$ chain genes in myelomas and hybridomas expressing different $\mathrm{H}$ chains do not necessarily reflect precursor-product relationships, as additional changes could have occurred in the genomes of these cells since the switch occurred. Furthermore, it is not known whether the deletions which appear to effect the switch occur in a single step or whether intermediate deletions occur.

If $\mathrm{H}$ chain switching is effected by deletion, individual cells should only be able to sustain the synthesis of two different $\mathrm{H}$ chains with the identical $V_{H}$ region by utilizing long-lived mRNA for one $\mathrm{H}$ chain until such stores of mRNA are exhausted. Indeed, individual cells have not been found to continuously synthesize two different $\mathrm{H}$ chains with the same $V_{\mathrm{H}}$ region, with the exception of $\mu$-and $\delta$-producing cells. The close proximity of the $\mu$ and $\delta$ genes appears 
to allow transcription of a single large RNA which can be spliced in alternate ways $(20,21$, 24).

The B cell lymphoma I.29, which is the subject of this report, consists of a mixture of cells expressing surface-associated $\operatorname{IgM}(\lambda)$ and $\operatorname{Ig} A$ $(\lambda)$ of identical $\mathrm{H}$ chain idiotypes (38). Most of the cells express either $\operatorname{IgM}(\lambda)$ or $\operatorname{IgA}(\lambda)$ alone, but 1 to $5 \%$ of the cells express both cytoplasmic and membrane-bound IgM and IgA simultaneously ( $38 ;$ R. Sitia, unpublished data). When $\mathrm{IgM}^{+}$cells were purified from the tumor and cultured in vitro, they converted entirely to $\mathrm{IgA}^{+}$in approximately 11 days (38). Similarly, IgM $^{+}$cells, on five consecutive passages in mice, showed a gradual change to $\operatorname{IgA}^{+}$cells until the proportions of $\operatorname{IgM}^{+}$and $\operatorname{IgA}^{+}$cells approximated those of the unsorted tumor (see Table 1). These properties suggest that I.29 may be a model for cells undergoing $H$ chain switching. We have as yet to prove that switching occurs in this system, as efforts to clone $\mathrm{IgM}^{+}$ cells in culture or in vivo have not been successful, and therefore it is possible that the few $\operatorname{IgA}^{+}$ cells which contaminate the $\mathrm{IgM}^{+}$cell preparations could overgrow the $\operatorname{IgM}^{+}$cells to produce the observed change to $\operatorname{IgA}^{+}$. The presence of double-producing cells, however, argues for the occurrence of active switching.

Since the $\operatorname{IgM}^{+}$and $\operatorname{IgA}^{+}$cells express the same idiotype and, apparently, the same germ line $V_{\mathrm{H}}$ gene and also contain the same rearrangement of a nonexpressed $C_{\kappa}$ gene (38; see below), the various cells of the I.29 lymphoma were probably derived from a single clone of cells. Hence, this lymphoma provides a system which can be used to examine the structure of immunoglobulin genes before and after switching in a single clone of cells. In this report, we examine the structure of immunoglobulin genes by restriction enzyme mapping of genomic DNAs isolated from a number of cloned cell lines and cell populations derived from the I.29 lymphoma. DNA deletions are clearly responsible for the switch in expression of $C_{\mathrm{H}}$ genes in the I.29 lymphoma.

\section{MATERIALS AND METHODS}

Cell lines. The B cell lymphoma I.29 arose spontaneously in the I/St mouse strain at the Sloan-Kettering Institute in $1961(34,35)$. The leukemia is maintained by intraperitoneal passage in $\mathrm{I} / \mathrm{St}$ mice or in (BALB/c $\times \mathrm{I} / \mathrm{St}) \mathrm{F}_{1}$ mice.

The cell lines used in these experiments were derived from the I.29 tumor as follows. The IgM-secreting hybridoma ID43 and the IgA-secreting hybridoma ID150 were derived by fusion of I.29 cells with the nonsecreting myeloma cell line P3-NS.1-Ag-8 (41). These hybridomas express only IgM or IgA, respectively. No double-producing hybridomas were obtained. Two cloned cell lines which express mem- brane-bound IgA, BFO1.1 and BFO.3, were derived by adaptation of $\mathrm{I} .29$ cells to culture (38). A noncloned cell line, IgM.S, was derived by culturing $10^{3} \mathrm{IgM}^{+}$ cells (obtained by sorting I.29 cells in a fluorescenceactivated cell sorter [FACS]) in Millipore filter chambers within the peritoneal cavities of I/St mice. Several chambers were inoculated, but only one chamber yielded I.29 cells, and these all expressed IgM of the I.29 idiotype. Cells were cultured in RPMI 1640 medium supplemented with $10 \%$ newborn calf serum, $2 \mathrm{mM}$ glutamine, penicillin $(100 \mathrm{U} / \mathrm{ml})$, and streptomycin $(100 \mu \mathrm{g} / \mathrm{ml})$.

Immunofluorescence and cell sorting. Production, purification, and characterization of most antibodies used in this study have been described in previous reports $(38,41)$. They are briefly characterized as follows. Antibody to mouse IgM was the culture fluid of the hybridoma R33/24, which secreted rat antibody to mouse $\mu$ chains (kindly provided by Gunter J. Hammerling, Heidelberg, West Germany). Antibody to IgA was prepared from rabbit antiserum to IgA (from ID150) by chromatography on solid-state ID150 protein, followed by absorptions with myeloma protein HOPC1 [IgG $(\lambda)$ ] to remove anti- $\lambda$ and with hybridoma ID43 to remove anti-k and anti-I.29 idiotypes. Anti-I.29 idiotype was a mouse monoclonal antibody derived from hybridoma T10/219 (42). Two other idiotype-specific antisera were prepared from rabbit antisera to hybridomas ID150 and ID43 by exhaustive absorption with normal mouse immunoglobulins and then with either IgA of MOPC 315 or IgM of TEPC183, respectively.

For all immunofluorescence experiments, I.29 tumor cells were taken from ascites after passage for 4 to 8 days in $\mathrm{I} / \mathrm{St}$ or $(\mathrm{BALB} / \mathrm{c} \times \mathrm{I} / \mathrm{St}) \mathrm{F}_{1}$ mice and cultured for $\mathbf{2} \mathrm{h}$ or overnight to remove cytophilic antibodies. Cells were labeled in suspension in a two-step procedure involving incubation with anti- $\alpha$, anti- $\mu$, or antiidiotype antibodies, followed by incubation with fluorescein-labeled, affinity-purified goat anti-rabbit IgG, rabbit anti-rat IgG, or rabbit anti-mouse $\mathrm{IgG} / \mathrm{Fc}$, respectively. A directly fluoresceinated anti- $\mu$ from hybridoma R33/24 was used in some experiments. A detailed account of serological and immunochemical characterizations of the I.29 tumor and derivative cell lines has been previously reported (38).

Cell-sorting experiments were performed with the FACS IV. For enriching $\mu^{+}$cells, $25 \%$ of the brightest-stained cells were collected. Analysis of these cells immediately after collection showed purities of 95 to $98 \%$. Preparations of lower purity were rejected. The immunoglobulins expressed in I.29 tumor cells, cell lines, and sorted cells were evaluated by immunofluorescence microscopy; the results concurred with published data (38).

Karyotype analysis. Karyotype analyses were performed by Giemsa band staining after denaturation of the chromosome, using a slight modification of the trypsin denaturation technique (37). The chromosomes were identified by referring to published studies $(7,25,28)$.

Restriction enzyme digestion, gel electrophoresis, and DNA blotting. Samples $(21 \mu \mathrm{g})$ of high-molecularweight DNA, isolated as described previously (3), were digested with the indicated restriction enzymes (purchased from New England Biolabs, Bethesda Research Laboratories, or Boehringer Mannheim Corp.). 
To monitor the extent of digestion, $5 \%$ of the reaction mixture was added to $0.3 \mu \mathrm{g}$ of pBR322 or $\lambda$ bacteriophage DNA and incubated along with the main reaction (13). The test samples were analyzed by electrophoresis in a $0.8 \%$ agarose gel in $40 \mathrm{mM}$ Trishydrochloride-20 mM acetate-18 mM NaCl-2 mM disodium EDTA (pH 8.1) (TEA-Na). When the digestion was complete, the DNA of the main reaction was precipitated with ethanol, and $10-\mu \mathrm{g}$ portions were electrophoresed on 6-mm-thick $0.7 \%$ agarose gels in TEA-Na.

DNA was transferred to nitrocellulose filters (39). The blots were baked, preannealed for 6 to $20 \mathrm{~h}$, and annealed for 3 days at $41^{\circ} \mathrm{C}$ with ${ }^{32} \mathrm{P}$-labeled restriction fragments in a solution containing $50 \%$ deionized formamide, $450 \mathrm{mM} \mathrm{NaCl}, 45 \mathrm{mM}$ sodium citrate, 0.3 $\mathrm{mM}$ disodium EDTA, $1 \mathrm{mg}$ of yeast RNA per $\mathrm{ml}, 100$ $\mu \mathrm{g}$ of Escherichia coli DNA per ml, and $0.02 \%$ each of bovine serum albumin, Ficoll, and polyvinyl pyrrolidone. The blots were washed in $0.1 \%$ sodium dodecyl sulfate-15 mM NaCl-0.1 mM disodium EDTA-1 mM phosphate (pH 6.8) at 50 to $52^{\circ} \mathrm{C}$ and were exposed at $-80^{\circ} \mathrm{C}$ to X-ray film (Kodak XR), using a Dupont Lightning Plus intensifying screen. If the blot was to be annealed with another probe, the first probe was removed by incubation of the blot at $68^{\circ} \mathrm{C}$ for 15 to 30 min in preannealing mix.

The restriction maps were determined by annealing the indicated probes to numerous Southern blots of single and double enzyme digests of DNAs from I.29 cells and from $\mathrm{I} / \mathrm{St}$ and BALB/c liver cells and by a comparison of our data with published data on BALB/c $\mu$ and $\alpha$ genes $(20,23,33)$. The restriction fragments obtained from the germ line $J_{\mathrm{H}^{-}} C \mu$ loci in $\mathrm{I} /$ St and BALB/c mice were identical, except for those which included the length variation region between the two HindIII sites located 1.5 and 5 kilobases (kb) $5^{\prime}$ to the $C \mu$ gene. The restriction enzyme sites which were altered in the rearranged $\mu$ genes could be located relative to the sites in germ line DNA by using the various probes indicated. The $\alpha$ gene in I strain mice is of a different allotype $(41,42)$ and has some restriction sites which differ from the $\alpha$ gene in BALB/c mice; the sites for $B g l \mathrm{II}$ and $\mathrm{KpnI}$ in the $\alpha$ gene were located by assuming that the $V_{\mathrm{H}}$ genes expressed with $C \mu$ and $C a$ were identical. The other sites were mapped as described for the $J_{\mathrm{H}^{-}}-C \mu$ loci. As we could locate only those restriction sites which produced fragments that annealed with the indicated probes, some sites for the enzymes we used are missing from our maps. The deletion events occurring within the intervening sequence in the expressed and nonexpressed chromosomes could be distinguished by comparing the bands detected by $\mathrm{pj}_{\mathrm{o}}$ and $\mathrm{pj}_{11}$ and also by comparing the bands detected in IgM.1P, IgM.S, and BFO cells, as these three cells contained different forms of the nonexpressed $J_{H}$ allele.

Plasmid purification and preparation of probes for hybridization. Plasmids were isolated from cleared lysates (by a modification of a previously described method [4]) by phenol-chloroform extraction at $\mathrm{pH} 4.0$ (46) and gel filtration on Sepharose 4B. Hybridization probes were prepared by isolation of restriction fragments from the plasmids. DNA probes were nicktranslated (31) to a specific activity of approximately 4 $\times 10^{8} \mathrm{cpm} / \mu \mathrm{g}$, using $\left[\alpha{ }^{32} \mathrm{P}\right] \mathrm{TTP}$ at $3,000 \mathrm{Ci} / \mathrm{mmol}$. All bacteria containing recombinant DNA were contained at the P1/EK1 level as specified by the National Institutes of Health Guidelines for Recombinant DNA Research.

Hybridization probes. The hybridization probe for $C \mu$ was a $B g l \mathrm{II} / H$ HindIII fragment isolated from the plasmid $\mathrm{p} \mu(3741)^{9}$ which contained cDNA coding for $C \mu$ (23). Figure 1A shows the sequences coding for the $C \mu$ probe (labeled $\mu$ ) on the restriction map of the I strain genomic $\mu$ gene. Probes for $J_{\mathrm{H}}$ genes were from the plasmid clones $\mathrm{pj}_{0}$ and $\mathrm{pj}_{11}$, which contain $\mathrm{BALB} / \mathrm{c}$ genomic DNA sequences coding for the $J_{\mathrm{H} 1}-J_{\mathrm{H} 2}$ $\left(J_{\mathrm{H} 1-2}\right)$ and the $J_{\mathrm{H} 3}-J_{\mathrm{H} 4}\left(J_{\mathrm{H} 3-4}\right)$ gene segments, respectively (23; Fig. 1A). pM2-20 contained a HindIII fragment of BALB/c genomic DNA sequences from the region $5^{\prime}$ to the $C \mu$ gene, which included the switch recombination $(S \mu)$ sequences (23). pM2-5B contained a HindIII insert of BALB/c genomic sequences which included the $5^{\prime}$ portion of the $C \mu$ gene and $5^{\prime}$ flanking sequences (23). The sequences contained in the genomic DNA clones are indicated on the restriction map of the I strain germ line $J_{\mathrm{H}^{-}} C \mu$ gene (Fig. 1A). The probe for $C \alpha$ was an $M s p I$ fragment containing nearly the entire $C \alpha$ sequence and isolated from the cDNA plasmid pa(J558) ${ }^{13}$ (23). The probe for $C \gamma 2 \mathrm{~b}$ was a Pst I/Kpn fragment isolated from the plasmid $\mathrm{p} \gamma 2 \mathrm{~b}(11)^{7}$ (36). The probe pBR1.4 contained BALB/c genomic DNA sequences from the $S \gamma 2 b$ region located 5 ' to $C \gamma 2 \mathrm{~b}$. The sequences used as the $S \gamma 2 \mathrm{~b}$ probe are indicated on the map of the germ line $C \gamma 2 \mathrm{~b}$ gene (18; see Fig. 4a). The probe for $C \gamma 3$ was a $6.6-\mathrm{kb}$ HindIII fragment containing the BALB/c germ line $C \gamma 3$ gene and flanking sequences prepared from the recombinant $\lambda$ phage SL51 (K. B. Marcu, L. W. Stanton, R. Lang, and $M$. Diamond, unpublished data). The probe for immunoglobulin $\lambda$ chain genes was an $\mathrm{HhaI}$ fragment containing cDNA coding for the entire $\lambda$ chain of the myeloma $\mathrm{H} 2020$ from the plasmid A12, which was similar to the plasmid B1 described previously (2). The probe for immunoglobulin $C \kappa$ sequences was a 730 base pair fragment containing cDNA sequences coding for $C K$ and a small portion of the $V$ region of the MOPC384 $\kappa$ chain isolated from the plasmid pM384 by HindIII digestion (40).

\section{RESULTS}

Restriction enzyme mapping of immunoglobulin genes in $\mathbf{I} .29$ cell lines: deletion of $\mu$ genes and rearrangement of $\alpha$ genes. To study the DNA rearrangements and deletions which accompany $\mathrm{H}$ chain switching in the $\mathrm{I} .29$ cell line, DNAs from several different cell lines and cell populations prepared from the I.29 lymphoma were digested with restriction enzymes and the DNA fragments were analyzed by DNA blotting (41). The blots were annealed with ${ }^{32} \mathrm{P}$-labeled cloned cDNAs or with cloned DNA sequences from the BALB/c genome containing immunoglobulin genes and their flanking sequences. The nucleotide sequences complementary to the probes used in the first series of experiments are indicated on the restriction maps of germ line $\mu$ and $\alpha$ genes of I strain mice (Fig. 1A); the probes are further described in Materials and Methods. 


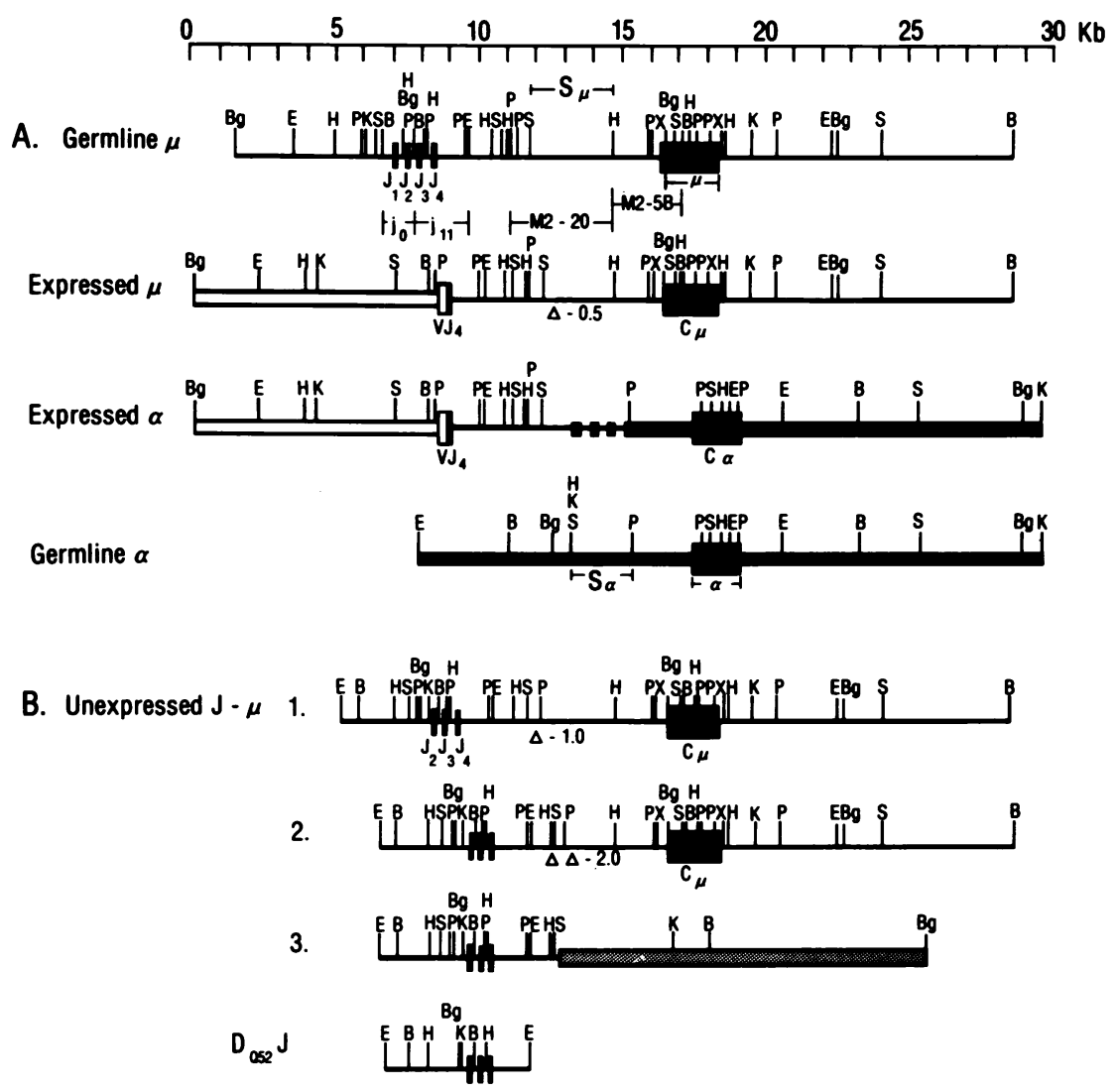

FIG. 1. Restriction enzyme maps of $\mu$ and $\alpha$ genes in I.29 and I strain liver cells. (A) Maps of the germ line $\mu$ and $\alpha$ genes in liver cells and of the expressed $\mu$ and $\alpha$ genes in I.29 cells. (B) Maps of the three fragments from the nonexpressed $J_{\mathrm{H}^{-}}-C \mu$ allele in I.29 cells compared with the map of the fragment produced by joining of the $D_{\mathrm{Q} 52}$ and $J_{\mathrm{H} 2}$ genes described in references 17 and 32 . The nucleotide sequences encoding the probes used to detect these fragments are indicated below the maps of the germline $\mu$ and $\alpha$ genes. $S \mu$ and $S \alpha$ indicate the regions in which switch recombination between the expressed $\mu$ and germ line $\alpha$ genes, respectively, appears to occur in I.29 cells. The site of recombination is within the $2.0-\mathrm{kb}$ region indicated by filled boxes on the expressed $\alpha$ gene. $\Delta-0.5, \Delta-1.0$, and $\Delta-2.0 \mathrm{~kb}$ indicate sites where DNA sequences have been deleted from the intervening sequence between $J_{\mathrm{H}_{4}}$ and $C \mu$. The thick horizontal lines and bars identified by $V, J$, and $C$ indicate coding sequences or potential coding sequences. DNA sequences which originate from different sites in the germ line DNA are indicated by different types of horizontal lines and bars. The DNA sequence, indicated by the shaded bar in (B-3), is derived from the $C \gamma 3$ gene. The site of recombination with the $S_{\mu}$ sequences is located 4 to $6 \mathrm{~kb} 5^{\prime}$ to the $C \gamma 3$ gene. The map of the $D_{\mathrm{Q} 52}-J_{\mathrm{H} 2}$ fragment was redrawn from the map of the cloned DNA fragment analyzed by Sakano et al. (32) and Kurosawa et al. (17), who did not map the SacI or PstI sites in their clone. The restriction enzyme sites identified are: B, BamHI; Bg, BglII; E, EcoRI; H, HindIII; K, KpnI; P, PstI; $\mathrm{S}, \mathrm{SacI}$; and X, XbaI.

DNA was prepared from populations of I.29 cells obtained by sorting the I. $29 \mu^{+}$cells on the FACS, using a monoclonal rat anti-mouse $\mu$ antibody and passaging these cells in mice (Table 1). These cell populations were termed IgM.1P, IgM.2P, etc., the number indicating the number of passages in mice after sorting. The proportions of cells expressing $\mu$ and $\alpha$ were determined by immunofluorescence. The ratio of $\alpha^{+}$to $\mu^{+}$cells generally increased during subsequent passages, although there was vari- ability among different experiments (Table 1). DNA was also prepared from the following cloned cell lines expressing either $\mu$ or $\alpha$ : $\operatorname{Ig} A^{+}$ cells obtained by cloning the tumor in vitro (BFO.3 and BFO1.1) (38), an IgM hybridoma (ID43), and an IgA hybridoma (ID150) derived from the fusion of I.29 tumor cells with the nonsecreting myeloma cell line P3-NS.1-Ag-8 (41). Thus far, no IgM cell line has been cloned from the I.29 lymphoma, as culture conditions conducive to growth of the $\mathrm{IgM}^{+}$cells in vitro 
TABLE 1. Cell populations and cell lines derived from the I.29 lymphoma

\begin{tabular}{|c|c|c|c|c|}
\hline \multirow[b]{2}{*}{ Designation } & \multirow[b]{2}{*}{ Assay } & \multicolumn{3}{|c|}{ \% Positive } \\
\hline & & $\mu^{+}$ & $\alpha^{+}$ & $\begin{array}{l}\text { Idio- } \\
\text { type }^{+}\end{array}$ \\
\hline \multicolumn{5}{|l|}{ Cell populations $^{a}$} \\
\hline IgM.1P & FACS & $99^{b}$ & 37 & 97 \\
\hline IgM.2P & FACS & 41 & 54 & 76 \\
\hline IgM.3P (prepn 1$)^{c}$ & FACS & 70 & 40 & $\mathrm{NT}^{d}$ \\
\hline IgM.3P (prepn 2) & FACS & 41 & 51 & $>90$ \\
\hline IgM.4P & FACS & 40 & 60 & NT \\
\hline IgM.5P & FACS & 17 & 77 & 93 \\
\hline \multicolumn{5}{|l|}{ Cell lines } \\
\hline ID43 (IgM hybridoma) & IFA & 100 & 0 & 100 \\
\hline ID150 (IgA hybridoma) & IFA & 0 & 100 & 100 \\
\hline BFO1.1, BFO. 3 & IFA & 0 & 100 & 100 \\
\hline IgM.S & $\begin{array}{l}\text { FACS, } \\
\text { IFA }\end{array}$ & $>95$ & 0 & $>95$ \\
\hline
\end{tabular}

${ }^{a}$ Mixed cell populations were obtained by sorting I.29 cells on the FACS and passaging the cells intraperitoneally in $\mathrm{I} / \mathrm{St}$ or in $(\mathrm{I} / \mathrm{St} \times \mathrm{BALB} / \mathrm{c}) \mathrm{F}_{1}$ mice. The cell populations indicated here were used in the restriction mapping experiments but were not all from the same FACS separation.

${ }^{b}$ The percentage of $\mu^{+}$cells in this preparation is inconsistent with those of two other preparations of IgM.1P cells, which were $70 \% \mu^{+}$and $30 \% \alpha^{+}$in preparation 1 and $45 \% \mu^{+}$and $44 \% \alpha^{+}$in preparation 2 . We believe that this is due to a problem with the FACS assay in the experiment shown above.

c The IgM.3P cells used in these experiments were derived from two independent sorting experiments (referred to as preparations 1 and 2 in the text).

${ }^{d}$ NT, Not tested.

have not been found. However, a line of $\operatorname{IgM}^{+}$ cells (IgM.S) which grows only in vivo without, as determined so far, switching to IgA expression, was derived by growing $\mathrm{IgM}^{+}$cells (obtained from the FACS) in Millipore chambers in mice (U. Hammerling and R. Chua, unpublished data). Livers of I/St mice were used as a source of germ line DNA since immunoglobulin genes in liver cells have been shown to be in the same context as in sperm or embryo cells $(8,15$, $22,44)$.

The genomic DNAs were digested with a number of restriction enzymes (as indicated in Fig. 1) in single and double enzyme digests. The fragments detected when DNAs were digested with $K p n I$ and annealed with $\mu$ cDNA are shown in Fig. 2A. The maps of these DNA segments are shown in Fig. 1, and the derivation of these maps are described below and in Materials and Methods. As Kpn has a recognition site located $5^{\prime}$ to the $J_{\mathrm{H}}$ genes in germ line DNA, joining of the $V_{\mathrm{H}}, D$, and $J_{\mathrm{H}}$ gene segments altered the $K p n$ fragment that annealed with $\mu$ cDNA (Fig. 1A). The $\mu$ genes on both chromosomes were rearranged in the IgM hybridoma and IgM.S cells, as these cells contained two Kpn fragments which both differed in size from the $K p n$ fragment in liver DNA (Fig. 2A). Note that the NS.1 plasma cells used for fusion to produce the hybridomas did not contain $C \mu$ genes (Fig. 2A, lane NS.1). From our extensive restriction mapping (see below and Fig. 1), we determined that the larger $K p n$ fragment $(15.3 \mathrm{~kb})$ in $\operatorname{IgM}^{+}$cells contained the expressed $\mu$ gene and was produced by a recombination near the $J_{\mathrm{H} 4}$ gene segment (Fig. 1A). The smaller Kpn fragment was produced by a recombination near the $J_{\mathrm{H}_{2}}$ gene segment on the nonexpressed chromosome. In addition, DNA sequences were deleted from the intervening sequence between the $J_{\mathrm{H}_{4}}$ and $C \mu$ genes at both $J_{\mathrm{H}^{-}} C \mu$ alleles (Fig. 1; see below). The last two lanes in Fig. 2A (BFO1.1 and IgA hybridoma) show that, in the BFO cells (cloned $\operatorname{IgA} \mathrm{A}^{+}$cells) and $\operatorname{IgA}$ hybridoma cells, the $C \mu$ genes were deleted from the expressed and nonexpressed chromosome. $\operatorname{Ig} \mathrm{A}^{+}$cells obtained by sorting I.29 tumor cells on the FACS also did not contain any $C \mu$ genes (data not shown).

When DNAs from cells which had been enriched for $\mu^{+}$on the FACS and subsequently passaged one to five times in mice were annealed with $\mu$ cDNA, we found that, as the proportion of $\mathrm{IgA}^{+}$cells increased, the intensity of the $\mu$ bands generally decreased (compare lanes containing DNA from IgM.S, IgM.3P [preparations 1 and 2], IgM.4P, and IgM.5P cells $\left[0,40,51,60\right.$, and $71 \% \alpha^{+}$, respectively] in Fig. $2 \mathrm{~A}$; the amount of IgM.1P DNA loaded onto the gel was less than that of the other DNAs, so the intensity of the bands in IgM.1P DNA cannot be compared with those of the other DNAs). The results shown in Fig. 2A demonstrated that $\mu$ genes are lost from both chromosomes as the proportion of the $\operatorname{IgA}^{+}$relative to $\operatorname{IgM}^{+}$cells increases.

A third $\mu$ fragment of $11 \mathrm{~kb}$ was detected in $K p n$ digests of DNA from the IgM.1P and IgM.3P (preparation 1) cell populations, in addition to the 15.3-kb fragment derived from the expressed chromosome and the 10-kb fragment derived from the nonexpressed chromosome. The presence of three $\mu$ fragments was not due to polyploidy of the I.29 cells, as karyotype analyses of 1.29 tumor cells, IgM.S cells, and BFO.3 cells indicated that each of these cells contained an average of two $\mathrm{H}$ chain chromosomes (chromosome 12) and an average of 41 chromosomes altogether (data not shown). Furthermore, the cloned cell lines contained only one fragment from the expressed $\mathrm{H}$ chain allele and one fragment from the nonexpressed allele. The restriction maps (Fig. 1B; see below) indicated that the 11-kb Kpn fragment was derived from the nonexpressed allele. As the 11-kb frag- 


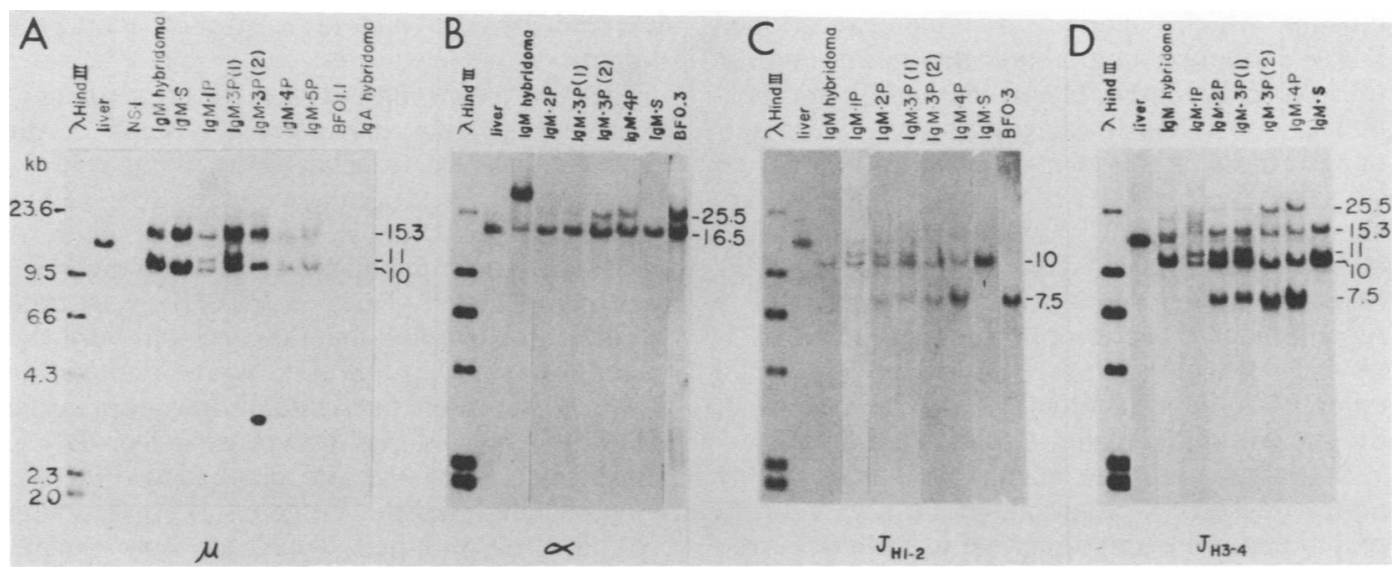

FIG. 2. Southern blots of KpnI digests of genomic DNAs from I.29 cell lines. Samples $(10 \mu \mathrm{g}) \mathrm{of}$ genomic DNAs from I.29 cells described in Table 1 were digested with $K p n I$, electrophoresed on $0.7 \%$ agarose gels, blotted to nitrocellulose, and annealed with ${ }^{32} \mathrm{P}$-labeled probes. (A) $\mu$ cDNA; (B) $\alpha \mathrm{cDNA}$; (C) BamHI fragment from pjo containing the $J_{\mathrm{H}_{1}}$ and $J_{\mathrm{H} 2}$ gene segments; (D) BamHI/EcoRI fragment from pj ${ }_{11}$ containing the $J_{\mathrm{H} 3}$ and $J_{\mathrm{H} 4}$ gene segments. The sizes of the fragments indicated on the right side of the blots were determined relative to the sizes of the HindIII fragments of $\lambda$ bacteriophage DNA, which had been labeled with $\left[\gamma-{ }^{32}\right.$ P]ATP by T4 polynucleotide kinase and electrophoresed in a parallel lane. The lanes in (A) and (D) of DNA from IgM.1P cells contained much less DNA than the other lanes; hence, the intensity of the bands in these lanes cannot be compared with the intensity of the bands in other lanes. NS.1 indicates P3-NS.1-Ag-8.

ment was not detected in DNA from late passages (IgM.4P and IgM.5P), this fragment may be a precursor to the $10-\mathrm{kb}$ fragment. The data from the restriction maps support this possibility (compare Fig. 1B-1 and 1B-2). It is also possible that the $11-\mathrm{kb}$ fragment is not a precursor to the $10-\mathrm{kb}$ fragment but was simply present in the population of $\operatorname{IgM}^{+}$cells selected by the FACS and that these cells were overgrown by cells containing the $10-\mathrm{kb}$ fragment during passage of the tumor. The 11-kb fragment was found only in the cell populations obtained by sorting the tumor cells and passaging them in vivo. Both the IgM hybridoma we examined and the IgM.S cells contained only the $10-\mathrm{kb} K p n$ fragment from the nonexpressed allele (Fig. 2A).

The Kpn fragments detected with ${ }^{32} \mathrm{P}$-labeled $\alpha$ cDNA are shown in Fig. 2B. The IgM hybridoma and IgM.S cells contained only the $16.5-\mathrm{kb}$ germ line $\alpha$ fragment. (The large fragment [ 40 to $60 \mathrm{~kb}$ ] detected in DNA from the IgM hybridoma contained $\alpha$ sequences contributed by the P3NS.1-Ag-8 genome.) As the FACS-sorted IgM ${ }^{+}$ cells were passaged in mice and the proportion of $\mathrm{IgA}^{+}$cells increased, a rearranged $\alpha$ fragment $(25.5 \mathrm{~kb})$ appeared and subsequently increased in intensity. In BFO cells, the rearranged $\alpha$ fragment was of an intensity similar to that of the germ line $\alpha$ fragment. The IgA hybridoma and IgA cells obtained by sorting the I.29 tumor cells on the FACS also appeared to contain an equimolar amount of the germ line and rearranged $\alpha$ gene fragments (data not shown).
I.29 DNAs were annealed with two different cloned $\mathrm{BALB} / \mathrm{c}$ genomic DNA sequences containing either the $J_{\mathrm{H} 1}$ and $J_{\mathrm{H}_{2}}$ genes $\left(\mathrm{pj}_{0}\right)$ or the $J_{\mathrm{H} 3}$ and $J_{\mathrm{H} 4}$ genes $\left(\mathrm{pj}_{11}\right)$ (23). The DNA segments contained in these probes are shown in Fig. 1A. The Kpn fragments detected with the $J_{\mathrm{H} 3-4}$ probe are shown in Fig. 2D. The $J_{\mathrm{H} 3-4}$ probe annealed with the same 13.6-kb fragment from liver DNA as did the $\mu$ cDNA probe. The $J_{\mathrm{H} 3-4}$ probe also annealed with the $K p n$ fragments containing the expressed $\mu(15.3 \mathrm{~kb})$ and $\alpha(25.5 \mathrm{~kb})$ genes and with the two $\mu$ fragments from the nonexpressed $\mathrm{H}$ chain allele (10 and 11 $\mathrm{kb})$. In addition, both $J_{\mathrm{H}}$ probes ( $\mathrm{pj}_{0}$ and $\mathrm{pj}_{11}$ ) detected a 7.5-kb $K p n$ fragment which did not anneal with the $\mu$ or $\alpha$ probes (compare Fig. 2A and $B$ with Fig. 2C and D). The map of this fragment is shown in Fig. 1B-3. The 7.5-kb Kpn fragment appears to be derived from the $10-\mathrm{kb}$ $K p n$ fragment or the 11-kb $K p n$ fragment, or both, from the nonexpressed $J_{\mathrm{H}}-C_{\mu}$ locus, since these three fragments had identical restriction maps on the $5^{\prime}$ side of the $J_{H}$ genes (Fig. 1B) and since the 7.5-kb band appeared to increase in intensity as the 11-kb fragment disappeared (Fig. 2D; compare lanes IgM.3P [preparation 1] and IgM.3P [preparation 2]). The 7.5-kb $J_{\mathrm{H}}$ fragment was absent from the IgM hybridoma and IgM.S cells and barely detectable in the IgM.1P population. The amount of this fragment increased when more $\operatorname{IgA} \mathrm{A}^{+}$cells were present in the population, and in BFO cells, it was the only portion of the $J_{\mathrm{H}^{-}}-C \mu$ locus from the nonexpressed chro- 
mosome which remained. By annealing a cloned DNA sequence containing the germ line $\gamma 3$ (described in Materials and Methods) with blots of I.29 cell DNAs (data not shown), we determined that this fragment contains a rearranged $\gamma 3$ gene. The sequences coding for $C \gamma 3$ are located immediately $3^{\prime}$ to the Bam site indicated on the stippled DNA sequence (Fig. 1B-3). This result has been confirmed by analysis of a recombinant $\lambda$ bacteriophage containing an 8.5kb Bam fragment from BFO cell DNA which contains $J_{H}$ gene segments and $\gamma 3$ sequences ( $J$. Stavnezer and S. Sirlin, unpublished data).

To summarize the results of mapping the nonexpressed $\mathrm{H}$ chain allele in I.29 cells, a recombination event appeared to have occurred at or near the $J_{\mathrm{H} 2}$ gene, since the HindIII, $B g l \mathrm{II}$, and $P$ st $\mathrm{I}$ sites between $J_{\mathrm{H} 1}$ and $J_{\mathrm{H} 2}$ were deleted (Fig. 1B). In addition, in cells which have switched from IgM to IgA synthesis, recombination events occurred in the intervening sequence between the $J_{\mathrm{H} 4}$ and $C \mu$ genes which resulted in the deletion of the $C \mu$ gene from the nonexpressed allele and the joining of the $J_{\mathrm{H}}$ genes with sequences located 4 to $6 \mathrm{~kb} 5^{\prime}$ to the $C \gamma 3$ gene. As the $\gamma 3$ switch recombination $(S \gamma 3)$ sequences are located between 1.7 and $5 \mathrm{~kb} 5^{\prime}$ to the $C \gamma 3$ gene $(16,18)$, this recombination was probably between $S \mu$ and $S \gamma 3$ sequences.

Identification of DNA fragments containing the expressed $\mu$ gene; mapping the expressed $V_{H}$ gene. To determine which of the three $\mu$ fragments detected in IgM.1P cells contains the expressed $\mu$ gene, the restriction maps of the $\mu$ gene fragments and the rearranged $\alpha$ gene fragment were compared. Since the $\mathrm{H}$ chain idiotypes of the IgM and IgA synthesized in I.29 cells are identical, we expected that the restriction maps of the DNA sequences located $5^{\prime}$ to the $J_{\mathrm{H}}$ genes in the rearranged $\alpha$ gene and in the expressed $\mu$ gene would be similar. The mapping data are consistent with this hypothesis. The $J_{\mathrm{H} 3-4}$ probe annealed with the rearranged $\alpha$ gene, whereas the $J_{\mathrm{H} 1-2}$ probe did not (Fig. $2 \mathrm{C}$ and D); hence, the expressed $\alpha$ gene has deleted the $J_{\mathrm{H} 1}$ and $J_{\mathrm{H}_{2}}$ gene segments. The larger of the two $\mu$ fragments $(15.3 \mathrm{~kb})$ in the IgM hybridoma and IgM.S cells also annealed with the $J_{\mathrm{H}_{3-4}}$ probe, but not with the $\boldsymbol{J}_{\mathrm{H} 1-2}$ probe, suggesting that this fragment bears the expressed $\mu$ gene (Fig. 2C and D). The HindIII site located between $J_{\mathrm{H} 3}$ and $J_{\mathrm{H} 4}$ in germ line DNA is missing from the expressed $\mu$ and $\alpha$ genes (Fig. 1A); hence, the $J_{\mathrm{H} 3}$ gene has probably been deleted, and $J_{\mathrm{H} 4}$ is probably expressed in I.29 cells. Proof that $J_{\mathrm{H} 1}$ and $J_{\mathrm{H} 2}$ were deleted from the expressed $\mu$ and $\alpha$ genes was provided by the finding that the $J_{\mathrm{H} 1-2}$ probe did not hybridize with blots of RNAs from various $I .29$ cell lines, whereas the $J_{\mathrm{H} 3-4}$ probe hybridized with RNAs of the same size as those detected by the $\mu$ and $\alpha$ probes (data not shown).

The restriction maps of the DNA sequences located $5^{\prime}$ to the rearranged $J_{\mathrm{H}_{4}}$ gene in the expressed $\mu$ and $\alpha$ genes were compared by digestion with restriction enzymes that cleave between $J_{\mathrm{H} 4}$ and the $S \mu$ sequences. Figure $3 \mathrm{~A}$ shows that the fragments produced by digestion with EcoRI, SacI, PstI, or HindIII or by both HindIII and BamHI together, which were detected by the $J_{\mathrm{H} 3-4}$ probe, were identical in DNAs from all of the I.29 cell lines expressing IgM or IgA but differed from those in liver DNA. These restriction sites are mapped in Fig. 1A. We concluded that the $V_{H}$ genes expressed with $C \mu$ and with $C \alpha$ in the I.29 cells are very similar.

Restriction maps of the fragments that annealed with the $J_{\mathrm{H} 1-2}$ probe indicated that the nucleotide sequences located $5^{\prime}$ to the $J_{\mathrm{H}}$ genes on the three $J_{H}$ fragments from the nonexpressed allele are also identical (or very similar) in all of the I.29 cell lines (Fig. 1B and 3B).

Site of switch recombination in $\mathbf{I . 2 9}$ cells. The sites at which DNA recombination occurred during switching from $\mu$ to $\alpha$ in the I.29 cells are within the tandemly repeated $S$ sequences identified in myeloma cells $(9,16,18,26,33)$. The site within the $S \mu$ sequence at which recombination with the $S \alpha$ sequence occurred in I.29 cells $[S \mu(\alpha)]$ was between the HindIII and SacI sites, which were located 2 and $4.5 \mathrm{~kb}$, respectively, $5^{\prime}$ to the $C \mu$ gene (Fig. 1A). The $S \mu(\alpha)$ sites in two IgA myelomas, T15 and M603, are located approximately $1 \mathrm{~kb} 5^{\prime}$ to this SacI site (9). The switch site $5^{\prime}$ to $C \alpha(S \alpha)$ was between the PstI and $S a c I$ sites located approximately 2 and $4 \mathrm{~kb}$, respectively, $5^{\prime}$ to the $C \alpha$ gene and indicated by filled boxes on the map of the expressed $\alpha$ gene (Fig. 1A).

If individual $\mathrm{I} .29$ cells were actively switching, the sites of DNA recombination could be expected to differ among different cells, because the nucleotide sequences of the $S \mu$ and $S \alpha$ regions consist of tandem direct repeats extending over approximately a 4 - and a $2.4-\mathrm{kb}$ region of DNA, respectively, and because the sites of switch recombination differ among different myelomas $(9,16,26,27,33)$. We attempted to detect heterogeneity in the $S \mu(\alpha)$ recombination site by comparing the sizes of SacI fragments containing the expressed $\alpha$ gene in three different cloned IgA cell lines, BFO.3, BFO1.1, and the IgA hybridoma. The two BFO cell lines were derived in the same experiment by seeding in separate wells $I .29$ tumor cells immediately after they were removed from a mouse (38); the $\operatorname{IgA}$ hybridoma was derived from $I .29$ cells taken from a different mouse at a different time (41). SacI produced a 6.1-kb fragment which contained both the expressed I.29 C $\alpha$ gene and the 


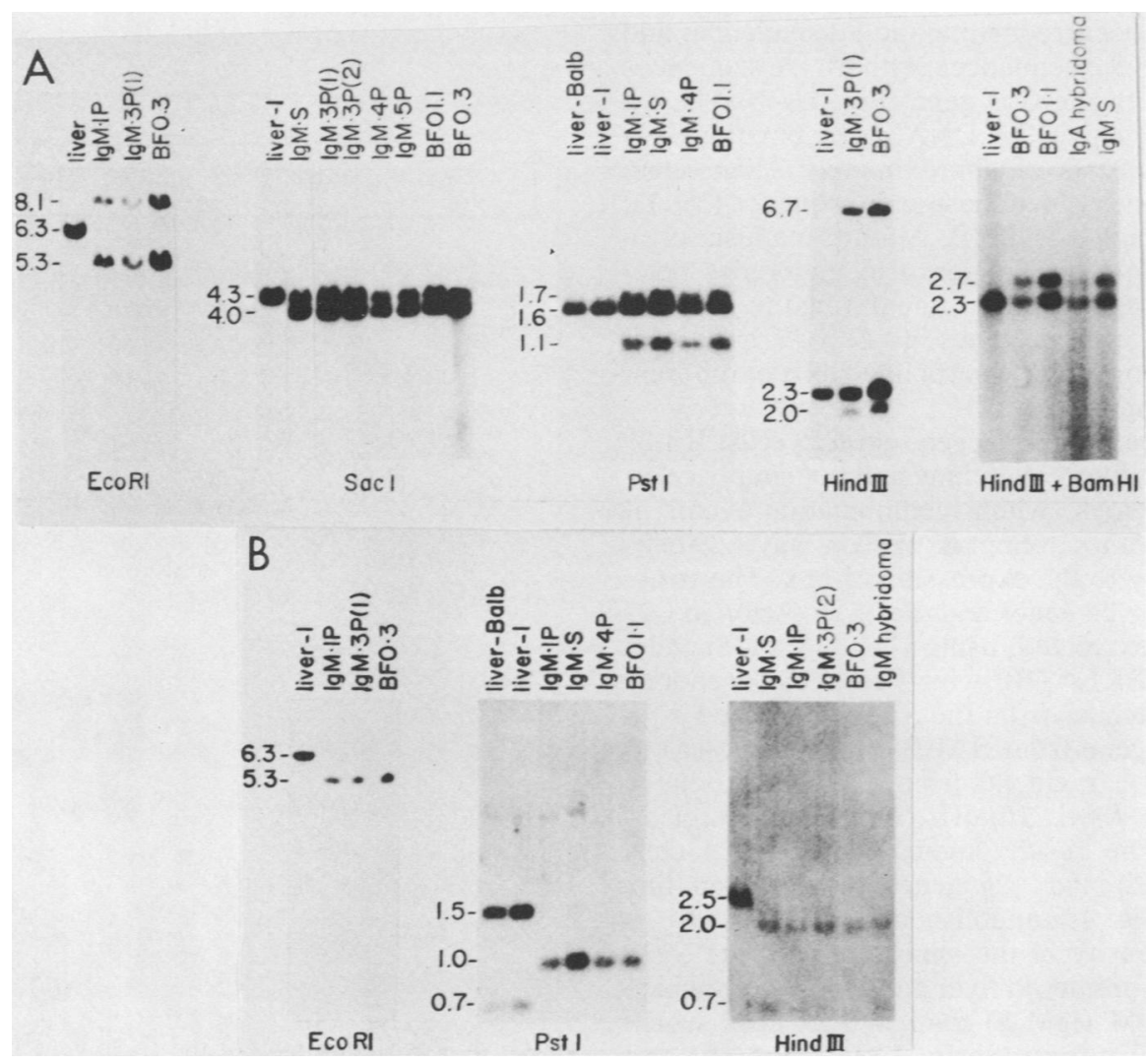

FIG. 3. Southern blots of genomic DNAs from I.29 cells annealed with $J_{H}$ probes. (A) Blots annealed with the $J_{\mathrm{H} 3-4}$ probe. (B) Blots annealed with the $J_{\mathrm{H} 1-2}$ probe. The sizes of the fragments indicated on the left side of each blot were determined relative to ${ }^{32} \mathrm{P}$-labeled HindIII fragments of $\lambda$ bacteriophage DNA which were electrophoresed in a parallel lane in each blot. The restriction enzymes used are indicated below each blot.

$S \alpha$ sequences located $5^{\prime}$ to the $C \alpha$ gene (Fig. 1A). If switch recombination occurred at sites separated from each other by $\geq 200$ base pairs in different cells, we would easily have detected the difference in the sizes of the $C \alpha$ fragments. A total of about 30 different SacI digestions which were electrophoresed on four DNA blots were compared, and no consistent difference in the sizes of the SacI fragments containing the expressed $\alpha$ gene was detected (data not shown). Furthermore, the restriction fragments bearing $J_{\mathrm{H}}, C \mu$, and $C \alpha$ genes in the noncloned population of FACS-sorted I.29 cells formed sharp bands on DNA blots that appeared to be as well defined as those obtained from the cloned BFO and hybridoma cells (Fig. 2; unpublished data). Thus, we found no evidence of heterogeneity among the sites of DNA recombinations in either the expressed or the nonexpressed $\mathrm{H}$ chain alleles in different $\mathrm{I} .29$ cells.

Deletions of DNA sequences from the switch recombination sites. By comparing the map of the germ line $J_{\mathrm{H}^{-}} C \mu$ allele with those of the expressed and nonexpressed $J_{\mathrm{H}^{-}}-C \mu$ alleles in I.29 cells, it can be seen that DNA sequences were deleted from the intervening sequence between the $J_{\mathrm{H} 4}$ and the $C \mu$ genes (Fig. 1). The deletions occurred near the $S \mu$ sequences between the two HindIII sites located approximately 1.5 and $5.3 \mathrm{~kb} 5^{\prime}$ to the germ line $C \mu$ gene (Fig. 1). The expressed $\mu$ gene suffered a $0.5-\mathrm{kb}$ deletion from the region in which switch recombination with the $C \alpha$ gene occurred in $I .29$ cells (Fig. 1A). Note that a PstI site has also been lost from the region located $5^{\prime}$ to the $S \mu$ sequences.

The two fragments from the nonexpressed allele which bore $C \mu$ underwent more extensive deletions than did those from the expressed allele in the $S \mu$ region and in the region just $5^{\prime}$ to the $S \mu$ region. The larger fragment underwent a 1-kb deletion (Fig. 1B-1). The smaller fragment appeared to have undergone two additional DNA recombinations which resulted in the deletion of another $1 \mathrm{~kb}$ of nucleotides (Fig. 1B-2). The recombination event which entirely deleted the $C \mu$ gene from the nonexpressed chromo- 
some also occurred within the $S \mu$ sequences and joined the $S \mu$ sequences with DNA sequences located 5 to the $\mathrm{C} \gamma 3$ gene (Fig. 1B-3). The $S \mu$ region, in which the DNA recombinations occurred, consists of approximately 200 tandem repeats of a 10 - to 40 -base-pair sequence $(26,33$; R. Greenberg and K. B. Marcu, manuscript in preparation). This region also undergoes deletions in myeloma DNAs and during the propagation of cloned $\mu$ genes in $E$. coli and is of variable length in the germ line DNA of different strains of mice $(22,23)$.

Structure of the $\gamma 2 \mathrm{~b}$ genes in I.29 cells. If I.29 cells are actively switching and not simply related by previous switch recombination events, it is important to attempt to explain why I.29 cells switch only to the expression of $\operatorname{IgA}$. The structure of the $\gamma 2 \mathrm{~b}$ genes and the $S \gamma 2 \mathrm{~b}$ region in I.29 cells was examined, using $\gamma 2 \mathrm{~b}$ cDNA (36) and a plasmid pBR1.4 (18) which contained genomic DNA sequences from the $S$ region located $5^{\prime}$ to the $C \gamma 2 \mathrm{~b}$ gene from BALB/c mice (Fig. $4 \mathrm{~A}$ ) to detect DNA fragments from $\mathrm{I} .29$ cells produced by EcoRI, KpnI, HindIII, BamHI, or SacI digestion. The results indicated that $I .29$ cells contain $\gamma 2 \mathrm{~b}$ and $\gamma 2 \mathrm{a}$ genes in the germ line context (Fig. 4; unpublished data).

The intensity of the annealing with the $S \gamma 2$ b probe was greater in liver and in I.29 cells which express IgM (IgM.S) than in I.29 cells which express predominantly IgA (IgM.4P and IgM.5P) or only IgA (BFO) (Fig. 4B and C). This result is consistent with the presence of $\gamma 2 b$ genes on both $\mathrm{H}$ chain chromosomes in $\mathrm{IgM}^{+}$ cells but on only one of the chromosomes in $\mathrm{IgA}^{+}$cells. As an internal control for the amount of DNA loaded onto each lane, the annealing of the $S \gamma 2 \mathrm{~b}$ probe with the blot containing SacI fragments (Fig. 4B) was compared with the annealing of the same blot with the $J_{\mathrm{H} 3-4}$ probe (Fig. 3A, SacI). The intensity of the bands detected with the $J_{\mathrm{H} 3-4}$ probe was approximately the same in the lanes containing DNA from liver, IgM.S, and BFO cells. Therefore, it appears likely that the switch from $\mu$ to $\alpha$ involves deletion of the $\gamma 2 \mathrm{~b}$ gene from the expressed allele. These results suggested that there is no alteration or deletion of the $\gamma 2 \mathrm{~b}$ genes or of the $S \gamma 2$ b sequences in I.29 cells, which would prevent switching from $\mu$ to $\gamma 2 \mathrm{~b}$. In addition, the $\mu$ and $\alpha$ genes were not closely juxtaposed in IgM $^{+}$cells, as the restriction maps of the $\mu$ genes present in liver and in IgM $^{+}$cells were identical for a distance of at least $10.5 \mathrm{~kb} \mathrm{3}^{\prime}$ to the $C \mu$ gene, and the maps of the $\alpha$ genes present in these same cells were identical for a distance of at least $9.5 \mathrm{~kb} \mathrm{5}^{\prime}$ to the $C \alpha$ gene (Fig. 1A; unpublished data). Thus, the $\mu$ and $\alpha$ genes are separated by at least $20 \mathrm{~kb}^{\text {in }} \mathrm{IgM}^{+}$cells.

Characteristics of the IgM.S cell line. An IgM ${ }^{+}$

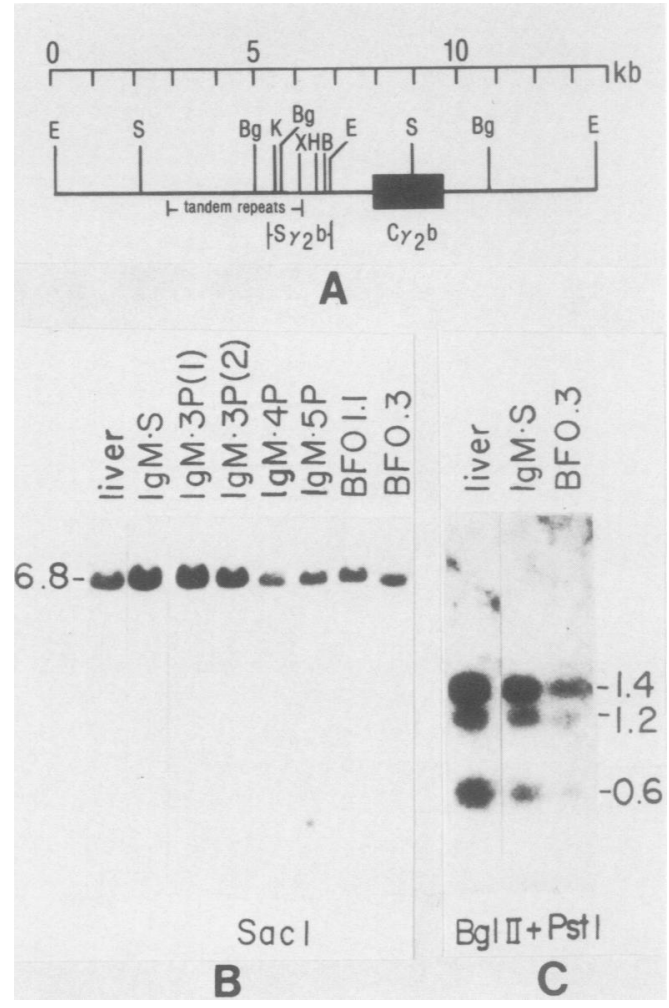

FIG. 4. Restriction map of the $C \gamma 2 \mathrm{~b}$ gene in germ line BALB/c cells and in I.29 cells. (A) This map (16, 18) corresponds with our map of the $C \gamma 2 \mathrm{~b}$ gene in $I .29$ cells extending from the EcoRI site located $8 \mathrm{~kb} 5^{\prime}$ to the $C \gamma 2 \mathrm{~b}$ gene to the EcoRI site located $4 \mathrm{~kb} \mathrm{3'}$ to the $C \gamma 2 b$ gene. The BALB/c DNA sequence contained within the $S \gamma 2 \mathrm{~b}$ probe is indicated below the map. The location of the tandemnly repeated sequences identified by Kataoka et al. (16) is indicated. The symbols for the enzyme sites are given in the legend to Fig. 1. (B) $S a c I$ fragments annealed with the $S \gamma 2$ b probe. This blot is the same blot of SacI fragments which is shown in Fig. 3A. The $J_{\mathrm{H}_{3-4}}$ probe had been removed by heating, and the blot was subsequently annealed with the $S$ y2b probe. (C) Southern blot of I.29 DNAs digested with both $B g I I I$ and $P s t I$ and annealed with the $S \gamma 2$ b probe.

cell line (IgM.S) which grows only in vivo and does not switch to IgA expression was derived from the I.29 lymphoma by seeding approximately $10^{3} \mathrm{IgM}^{+}$cells obtained by the FACS into each of several Millipore filter chambers which were then placed into the peritoneal cavity of $(\mathrm{I} / \mathrm{St} \times \mathrm{BALB} / \mathrm{c}) \mathrm{F}_{1}$ mice. Only one of the chambers yielded I.29 cells, all of which were $\mathrm{IgM}^{+}$. These $\mathrm{IgM}^{+}$cells were then passaged intraperitoneally in mice for several passages, and only IgM $^{+}$cells were obtained. As was true for other $\mathrm{IgM}^{+}$cells of the I.29 lymphoma, we 
did not find conditions which would support the growth of the IgM.S cell line in vitro.

To attempt to determine whether IgM.S cells do not switch to $\operatorname{IgA}$ expression because of a deletion or other defect in their $\mathrm{H}$ chain genes, we compared the restriction enzyme maps of the $\mathrm{H}$ chain genes in the IgM.S cells with those of the $\mathrm{H}$ chain genes in the IgM hybridoma and mixed $\operatorname{IgM}{ }^{+}-\operatorname{Ig} \mathrm{A}^{+}$cell populations. No deletion or other defect in the $\mathrm{H}$ chain genes of the IgM.S cells was detected. The restriction maps of the expressed and nonexpressed $J_{\mathrm{H}^{-}} C \mu$ genes and of the $\alpha$ and $\gamma 2 b$ genes in the IgM.S and IgM hybridoma cells were identical (excluding the P3-NS.1-Ag-8 contribution to the hybridoma cell line [Fig. 1 through 4; unpublished data]). In both the IgM.S and IgM hybridoma cells, there was only one Kpn fragment from the nonexpressed $\mu$ allele, the intermediate-sized $(10-\mathrm{kb})$ fragment. Apparently, the IgM.S and IgM hybridoma cells were both arrested at the same stage of, or before, the switching process. We do not know the frequency of occurrence of cells such as the IgM.S cells in the I.29 lymphoma, although by examining the $\mu$ genes in IgM.1P cells (Fig. 2A), we can conclude that no more than $50 \%$ of the IgM.1P cells have the nonexpressed $\mu$ gene in the same form as that found in IgM.S cells.

Rearrangement of light chain genes in $\mathbf{I} .29$ cells. I. 29 cells express a $\lambda$ light chain. Cell lines which express $\lambda$ chains usually have rearranged or deleted both of their $C_{\kappa}$ genes, in addition to having rearranged one or more $C \lambda$ genes. By contrast, cells which synthesize $\kappa$ chains do not contain rearranged $\lambda$ genes $(6,11)$. Our data are consistent with the results in other systems. When EcoRI or BamHI fragments of IgM.1P and BFO cell DNAs were annealed with a $C_{K}$ cDNA probe (pM384k [40]), one rearranged $C_{\kappa}$ fragment of identical size was detected in both of these types of cells (Fig. 5A), whereas annealing a probe for a $\lambda 1$ light chain (2) with EcoRI or BamHI digests of IgM.1P and BFO cell DNAs revealed two rearranged $\lambda$ fragments in addition to the germ line $\lambda$ fragments (Fig. 5B). These results provide further proof that the $\mathrm{IgM}^{+}$and $\mathrm{IgA}^{+}$cells of the I.29 lymphoma were derived from the same parental cell.

\section{DISCUSSION}

Are I.29 cells undergoing active switching? The I.29 lymphoma may contain cells which can switch from the synthesis of immunoglobulin $\mu$ chains to the synthesis of immunoglobulin $\alpha$ chains. However, since $\operatorname{IgM}^{+}$cells have not been cloned from the lymphoma, one could alternatively hypothesize that the I.29 lymphoma consists of four distinct types of cells which are related by previous switch events and which

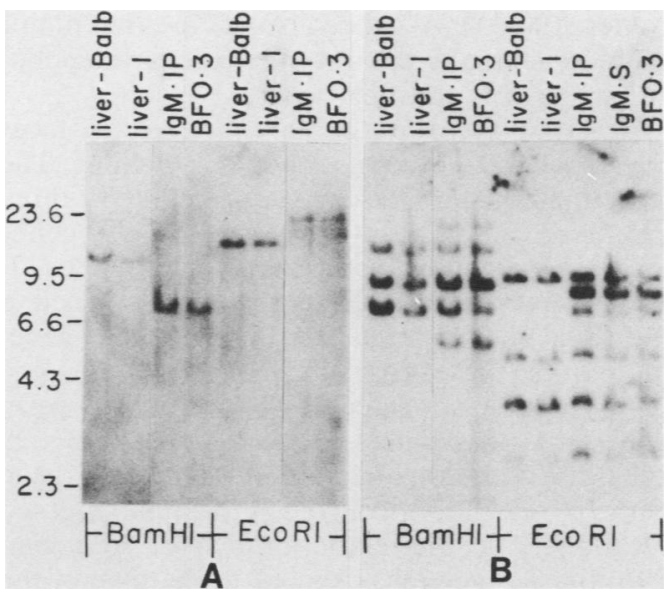

FIG. 5. Southern blots of genomic DNAs annealed with probes for immunoglobulin light chain genes. (A) Blot annealed with $C_{\kappa}$ cDNA. (B) Blot annealed with $\lambda \mathrm{H} 2020 \mathrm{cDNA}$. The positions of the HindIII fragments of $\lambda$ DNA which were electrophoresed in each gel are indicated on the left. The enzymes used are indicated at the bottom of the lanes.

have continued to coexist in the transplanted tumor during 21 years of in vivo passage. Our Southern blotting experiments indicated that there are two different types of $\mathrm{IgM}^{+}$cells, those containing the nonexpressed $\mu$ allele in the form of the 11-kb Kpn fragment and those containing the nonexpressed $\mu$ allele in the form of the 10kb $K p n$ fragment. Karyotype analyses indicated that the I.29 cells are diploid; thus, these two different forms of the nonexpressed allele do not exist in the same cell. Furthermore, cloned $\mathrm{IgM}^{+}$hybridoma cells (ID43) and the $\mathrm{IgM}^{+}$line which has never been observed to switch (IgM.S) contain only one of the forms of the nonexpressed allele (the 10-kb Kpn fragment). The other cell types present in the lymphoma are the $\mathrm{IgA}^{+}$cells and the double-producing cells. The presence of double-producing cells constitutes the strongest argument for the occurrence of active switching, as double-producing cells could be cells which have recently switched to synthesis of $\alpha$ chains but still contain residual $\mu$ mRNA and $\mu$ chains.

If $I .29$ cells are undergoing active switching, it is necessary to explain why the tumor does not become $100 \% \mathrm{IgA}^{+}$; the $\operatorname{IgA}^{+}$cells cannot revert to IgM expression, since our data proved that the $\mu$ genes have been deleted from $\operatorname{IgA}{ }^{+}$ cells. One could hypothesize that switching occurs during DNA replication (43), that only one of the two daughter cells switches to $\operatorname{Ig} \mathrm{A}^{+}$, and that, thus, the IgM ${ }^{+}$cells would not be depleted. The presence of IgM.S-like cells in the lymphoma cannot explain why the tumor never be- 
comes $100 \% \mathrm{IgA}^{+}$, because if so, the tumor should eventually consist of two separate populations, IgM.S and $\operatorname{IgA}^{+}$cells.

Rearrangement at the nonexpressed $J_{H}$ locus may involve $D-J$ joining without $V-D$ joining. The structures of the DNA rearrangements in three examples of aberrantly rearranged $J_{H}$ genes round in $\mathrm{B}$ and $\mathrm{T}$ cells have been determined (17, 32). In all three examples, a $D$ gene was joined to the $J_{\mathrm{H} 2}$ gene without association with a $V_{\mathrm{H}}$ gene; in two of these cases, the identical $D$ gene

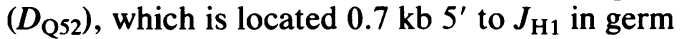
line DNA, was joined to the $J_{\mathrm{H} 2}$ gene. In I.29 cells, the same recombination of the $D_{\mathrm{Q} 52}$ gene with $J_{\mathrm{H} 2}$ may have occurred at the nonexpressed $J-C \mu$ allele, as the restriction map of the region $5^{\prime}$ to the $J_{\mathrm{H} 2}$ gene was similar to the map of the $D_{\mathrm{Q} 52}-J_{\mathrm{H} 2}$ rearrangement. The map of the $D_{\mathrm{Q} 52^{-}}$ $J_{\mathrm{H} 2}$ rearrangement is shown below Fig. 1B-3 (32). The mechanism of allelic exclusion in I.29 cells could involve the recombination of a $D$ gene with a $J$ gene without association with a $V_{H}$ gene.

\section{ACKNOWLEDGMENTS}

We thank Roberto Sitia and Nobuhiko Tada for communication of results before publication; Gunter Hammerling for antibody; Susumu Tonegawa for the plasmid clone A12; Robert Perry for the plasmid clone py $2 b(11)^{7}$; Kathy Slavin, Gilbert Olini, and Ramon Chua for excellent technical assistance; and Briann Packard for photography.

This research was supported by Public Health Service grants AI 14831, AI GM14617, BRSG 07RR05534, CA 087 48, and GM-26939 from the National Institutes of Health and a Basil O'Connor grant (5-255) from The March of Dimes Birth Defects Foundation.

\section{LITERATURE CITED}

1. Abney, E. R., M. D. Cooper, J. F. Kearney, A. R. Lawton, and R. M. E. Parkhouse. 1978. Sequential expression of immunoglobulin on developing mouse B lymphocytes: a systematic survey that suggests a model for the generation of immunoglobulin isotype diversity. J. Biol. Chem. 120:2041-2049.

2. Brack, C., M. Hirama, R. Lenhard-Schuller, and S. Tonegawa. 1978. A complete immunoglobulin gene is created by somatic recombination. Cell 15:1-14.

3. Cayre, Y., M. A. Palladino, K. B. Marcu, and J. Stavnezer. 1981. Expression of an antigen receptor on $\mathrm{T}$ cells does not require recombination at the immunoglobulin $\mathrm{J}_{\mathrm{H}^{-}}$ $\mathrm{C} \mu$ locus. Proc. Natl. Acad. Sci. U.S.A. 78:3814-3818.

4. Clewell, D. B., and D. R. Helinski. 1969. Supercoiled circular DNA-protein complex in Escherichia coli: purification and induced conversion to an open circular DNA form. Proc. Natl. Acad. Sci. U.S.A. 62:1159-1166.

5. Coleclough, C., D. Cooper, and R. P. Perry. 1980. Rearrangement of immunoglobulin heavy chain genes during $B$ lymphocyte development as revealed by studies of mouse plasmacytoma cells. Proc. Natl. Acad. Sci. U.S.A. 77:1422-1426.

6. Coleclough, C., R. P. Perry, K. Karjalainen, and $M$. Weigert. 1981. Aberrant rearrangements contribute significantly to the allelic exclusion of immunoglobulin gene expression. Nature (London) 290:372-378.

7. Committee on Standard Genetic Nomenclature for Mice. 1972. Standard karyotype of the mouse, Mus musculus. J. Hered. 63:69-72.
8. Cory, S., and J. M. Adams. 1980. Deletions are associated with somatic rearrangement of immunoglobulin heavy chain genes. Cell 19:37-51.

9. Davis, M. M., S. K. Kim, and L. Hood. 1980. DNA sequences mediating class switching in $\alpha$-immunoglobulins. Science 209:1360-1365.

10. Gearhart, P. J., J. L. Hurwitz, and J. J. Cebra. 1980. Successive switching of antibody isotypes expressed within the lines of a B-cell clone. Proc. Natl. Acad. Sci. U.S.A. 77:5424-5428.

11. Heiter, P. A., S. J. Korsmeyer, T. A. Waldmann, and P. Leder. 1981. Human immunoglobulin $\kappa$ light-chain genes are deleted or rearranged in $\lambda$-producing $B$ cells. Nature (London) 290:368-372.

12. Honjo, T., and T. Kataoka. 1978. Organization of immunoglobulin heavy chain genes and allelic deletion model. Proc. Natl. Acad. Sci. U.S.A. 75:2140-2144.

12a.Honjo, T., T. Kataoka, Y. Yaoita, A. Shimizu, N. Takahashi, Y. Yamawaki-Kataoka, T. Nikaido, S. Nakai, M. Obata, T. Kawakami, and Y. Nishida. 1981. Organization and reorganization of immunoglobulin heavy chain genes. Cold Spring Harbor Symp. Quant. Biol. 45:913-923.

13. Hughes, S. M., P. R. Shank, D. H. Spector, H. J. Kung, J. M. Bishop, and H. E. Varmus. 1978. Proviruses of avian sarcoma virus are terminally redundant, co-extensive with unintegrated linear DNA and integrated at many sites. Cell 15:1397-1410.

14. Hurwitz, J. L., C. Coleclough, and J. J. Cebra. 1980. $C_{H}$ gene rearrangements in IgM-bearing $B$ cells and in the normal splenic DNA component of hybridomas making different isotypes of antibody. Cell 22:349-359.

15. Joho, R., I. L. Weissman, P. Early, J. Cole, and L. Hood. 1980. Organization of $\kappa$ light chain genes in germ-line and somatic tissue. Proc. Natl. Acad. Sci. U.S.A. 77:11061110.

16. Kataoka, T., T. Miyata, and T. Honjo. 1981. Repetitive sequences in class-switch recombination regions of immunoglobulin heavy chain genes. Cell 23:357-368.

17. Kurosawa, Y., H. Von Boehmer, W. Haas, H. Sakano, A. Trauneker, and S. Tonegawa. 1981. Identification of D segments of immunoglobulin heavy-chain genes and their rearrangement in $\mathrm{T}$ lymphocytes. Nature (London) 290:565-570.

18. Lang, R. B., L. W. Stanton, and K. B. Marcu. 1982. On immunoglobulin heavy chain gene switching: two $\gamma 2 \mathrm{~b}$ genes are rearranged via switch sequences in MPC-11 cells but only one is expressed. Nucleic Acids Res. 10:611-630.

19. Lawton, A. R., P. W. Kincade, and M. D. Cooper. 1975. Sequential expression of germline genes in the development of immunoglobulin class diversity. Fed. Proc. 34:3339.

20. Liu, C. P., P. W. Tucker, J. F. Mushinski, and F. R. Blattner. 1980. Mapping of heavy chain genes for mouse immunoglobulins M and D. Science 209:1348-1352.

21. Maki, R., W. Roeder, A. Traunecker, C. Sidman, M. Wabl, W. Raschke, and S. Tonegawa. 1981. The role of DNA rearrangement and alternative RNA processing in the expression of immunoglobulin delta genes. Cell 24:353-365.

22. Marcu, K. B., N. Arnheim, J. Banerji, N. A. Penncavage, P. Separack, R. Lang, R. Miesfeld, L. Harris, and R. Greenberg. 1981. Studies on the nature and germline stability of DNA sequences flanking the mouse immunoglobulin heavy-chain constant-region genes. Cold Spring Harbor Symp. Quant. Biol. 45:899-911.

23. Marcu, K. B., J. Banerji, N. A. Penncavage, R. Lang, and N. Arnheim. 1980. 5' flanking region of immunoglobulin heavy chain constant region genes displays length heterogeneity in germlines of inbred mouse strains. Cell 22:187196.

24. Moore, K. W., J. Rogers, T. Hunkapiller, P. Early, C. Nottenburg, I. Weissman, H. Bazin, R. Wall, and L. Hood. 1981. Expression of IgD may use both DNA rearrangement and RNA splicing mechanisms. Proc. Natl. Acad. 
Sci. U.S.A. 78:1800-1804.

25. Nesbitt, M. N., and U. Francke. 1973. A system of nomenclature for band patterns of mouse chromosomes. Chromosoma 41:145-158.

26. Nikaido, T., S. Nakai, and T. Honjo. 1981. The switch (S) region of the immunoglobulin $\mathrm{C} \mu$ gene is composed of simple tandem repetitive sequences. Nature (London) 292:845-848.

27. Obata, M., T. Kataoka, S. Nakai, H. Yamagishi, N. Takahashi, Y. Yamawaki-Kataoka, T. Nikaido, A. Shimizu, and T. Honjo. 1981. Structure of a rearranged $\gamma 1$ chain gene and its implication to immunoglobulin class-switch mechanism. Proc. Natl. Acad. Sci. U.S.A. 78:2437-2441.

28. Ohno, S., M. Babonits, F. Wiener, J. Spira, G. Klein, and M. Potter. 1979. Nonrandom chromosome changes involving the Ig gene-carrying chromosomes 12 and 16 in pristane-induced mouse plasmacytomas. Cell 18:10011007.

29. Parkhouse, R. M. E., and M. D. Cooper. 1977. A model for the differentiation of B lymphocytes with implications for the biological role of IgD. Immunol. Rev. 37:105-126.

30. Pernis, B., L. Forni, and A. L. Luzzati. 1976. Synthesis of multiple immunoglobulin classes by single lymphocytes. Cold Spring Harbor Symp. Quant. Biol. 41:175-183.

31. Rigby, P. W. J., M. Dieckmann, C. Rhodes, and P. Berg. 1977. Labeling deoxyribonucleic acid to high specific activity in vitro by nick translation with DNA polymerase I. J. Mol. Biol. 113:237-251.

32. Sakano, H., Y. Kurosawa, M. Weigert, and S. Tonegawa. 1981. Identification and nucleotide sequence of a diversity DNA segment (D) of immunoglobulin heavy-chain genes. Nature (London) 290:562-565.

33. Sakano, H., R. Maki, Y. Kurosawa, W. Roeder, and S. Tonegawa. 1980. Two types of somatic recombination are necessary for the generation of complete immunoglobulin heavy-chain genes. Nature (London) 286:676-683.

34. Sato, H., and E. A. Boyse. 1976. A new alloantigen expressed selectively on B cells: the Lyb-2 system. Immunogenetics 3:565-572.

35. Sato, H., E. A. Boyse, T. Aoki, C. Iritani, and L. J. Old. 1973. Leukemia-associated transplantation antigens related to murine leukemia virus. The X.1 system: immune response controlled by a locus linked to H-2. J. Exp. Med. 138:593-606.
36. Schibler, U., K. B. Marcu, and R. P. Perry. 1978. The synthesis and processing of the messenger RNAs specifying heavy and light chain immunoglobulins in MPC-11 cells. Cell 15:1495-1509.

37. Seabright, M. 1972. The use of proteolytic enzymes for the mapping of structural rearrangement in the chromosomes of man. Chromosoma 36:204-210.

38. Sitia, R., A. Rubartelli, and H. Hammerling. 1981. Expression of two immunoglobulin isotypes, IgM and $\operatorname{IgA}$, with identical idiotypes in the B cell lymphoma I.29. J. Immunol. 127:1388-1394.

39. Southern, E. 1975. Detection of specific sequences among DNA fragments separated by gel electrophoresis. J. Mol. Biol. 98:503-517.

40. Stavnezer, J., J. P. McGrath, K. J. Slavin, R. Li, Y. Li, R. Herz, and B. Alhadefi. 1981. The numbers and rearrangements of genes in the T15 $\kappa$ group. Immunoglobulin idiotypes and their expression, p. 59-73. In C. Janeway, E. E. Sercarz, H. Wigzell, and C. F. Fox (ed.), ICNUCLA Symposium on Molecular and Cellular Biology, XX. Academic Press, Inc., New York.

41. Tada, N., and U. Hammerling. 1980. Secretion of either of a pair of immunoglobulins, IgM or IgX, in somatic hybrid cells derived by fusion of a B-cell lymphoma cell line carrying both immunoglobulin isotypes. Immunogenetics 11:7-19.

42. Tada, N., S. Kimura, R. Binari, Y. Liu, and U. Hammerling. 1981. New mouse immunoglobulin A heavy chain allotype specificities detected using the hybridoma-derived IgA of $\mathrm{U} / \mathrm{St}$ mice. Immunogenetics 13:475-481.

43. Vander Loo, W., E. Severinson-Gronowicz, S. Strober, and L. A. Herzenberg. 1979. Cell differentiation in the presence of cytochalasin B: studies on the "switch" to IgG secretion after polyclonal B cell activation. J. Immunol. 122:1203-1208.

44. Wilson, R., J. Miller, and U. Storb. 1979. Rearrangement of immunoglobulin genes. Biochemistry 18:5013-5021.

45. Yaoita, Y., and T. Honjo. 1980. Deletion of immunoglobulin heavy chain genes from expressed allelic chromosome. Nature (London) 286:850-853.

46. Zasloff, M., G. D. Ginder, and G. Felsenfeld. 1978. A new method of the purification and identification of covalently closed circular DNA molecules. Nucleic Acids Res. 5:1139-1152. 